\title{
Management of acute alcohol withdrawal in the setting of a quick diagnostic unit integrated in an emergency department setting
}

\author{
Pernille Würtz Bøhm*, Tove Beyer Fuglevig Mortensen, Thomas Andersen Schmidt \\ From Proceedings of the 5th Danish Emergency Medicine Conference \\ Aarhus, Denmark. 18-19 April 2013
}

\section{Background}

Alcohol consumption can have adverse social, legal, occupational, psychological, and medical consequences. The prevalence of alcohol-use disorders is high in Emergency Departments. The novel establishment of a Quick Diagnostic Unit (QDU) in an ED setting has allowed expeditious and focused, medically supervised acute alcohol withdrawal. The purpose of the study was to describe the alcohol-use disorder clientele and treatment in this new setting.

\section{Methods}

Chart review of an 8 month period April to December 2012. Values were given as means \pm SEM. Significance was evaluated using Student's two-tailed t-test for unpaired observations or Fisher's exact test as appropriate. The level of significance was established at $\mathrm{p}<0.05$.

\section{Results}

A total of 91 patients were included in the study, 74 men and 17 women. The patients in total amounted to $2.6 \%$ of the discharged patients from the QDU. There was no age difference between men and women, i.e. $51.2 \pm 1.5$ years vs $50.6 \pm 2.5$ years ( $p>0.80)$. Length of stay was $1.8 \pm$ 0.2 days for men vs $2.5 \pm 0.6$ days for women ( $>0.2)$. In $19 \%$ of the cases men held jobs, whereas none of the women were employed $(\mathrm{p}<0.0001)$.

Among patients who received chlordiazepoxide (RisolidR) for withdrawal symptoms the total dose was $405 \pm$ $43 \mathrm{mg}(\mathrm{n}=53)$ among men vs $494 \pm 105 \mathrm{mg}(\mathrm{n}=14)$ among women ( $\mathrm{p}>0.30)$. Thus $72 \%$ of the men vs $82 \%$ ( $\mathrm{p}$ $>0.10$ ) of the women were in need of chlordiazepoxide.

\footnotetext{
* Correspondence: pwm@regionsjaelland.dk

The Emergency Department, Holbæk Hospital, Denmark
}

There were no differences between men and women with regard to need for ICU care or emergent psychiatric refer$\mathrm{ral}(\mathrm{p}>0.20)$. Men left the QDU against medical advice to a greater extent than women, i.e. $22 \%$ vs $6 \%(\mathrm{p}<0.002)$.

\section{Conclusion}

Women with alcohol-use disorders appear to be more marginalized than men. Thus, they are employed to a lesser extent than men, and numerically they are treated more frequently and with a higher total dose of chlordiazepoxide. Men are more capable or prone than women to reject treatment. Further studies of the QDU setting would be beneficial.

Published: 9 September 2013

doi:10.1186/1757-7241-21-S2-A6

Cite this article as: Bøhm et al.: Management of acute alcohol withdrawal in the setting of a quick diagnostic unit integrated in an emergency department setting. Scandinavian Journal of Trauma, Resuscitation and Emergency Medicine 2013 21(Suppl 2):A6.

Submit your next manuscript to BioMed Central and take full advantage of:

- Convenient online submission

- Thorough peer review

- No space constraints or color figure charges

- Immediate publication on acceptance

- Inclusion in PubMed, CAS, Scopus and Google Scholar

- Research which is freely available for redistribution 